\title{
Algoritma berhitung Blijâh pada masyarat Madura di Kabupaten Probolinggo: Alternatif pendekatan pembelajaran operasi bilangan
}

\author{
Loviga Denny Pratama*, Wahyu Setyaningrum \\ Program Studi Pendidikan Matematika, Program Pascasarjana, Universitas Negeri Yogyakarta. \\ Jalan Colombo No. 1, Karangmalang, Yogyakarta 55281, Indonesia \\ * Corresponding Author. E-mail: loviga.denny2016@student.uny.ac.id \\ Received: 16 September 2018; Revised: 17 October 2018; Accepted: 21 December 2018
}

\begin{abstract}
Abstrak
Studi ini bertujuan untuk mendeskripsikan algoritma berhitung pada transaksi jual-beli yang dilakukan Blijâh (penjual sayur tradisional) dalam masyarakat Madura di Kabupaten Probolinggo, Indonesia. Studi ini merupakan studi kualitatif dengan pendekatan studi kasus. Data dikumpulkan dengan teknik observasi dan wawancara. Sumber data adalah 8 orang Blijâh yang tinggal di Kecamatan Paiton, Kabupaten Probolinggo, Indonesia. Analisis data dilakukan dengan menggunakan model Miles \& Huberman, dengan tahapan analisis meliputi reduksi data, penyajia datam dan penyimpulan. Data yang diperoleh berupa data kualitatif yang menggambarkan beberapa algoritma berhitung yang terdiri dari penjumlahan, pengurangan, perkalian dan pembagian. Adapun dalam artikel ini akan fokus pada algoritma penjumlahan dan pengurangan. Hasil studi menunjukkan bahwa (1) algoritma berhitung penjumlahan dan pengurangan yang dilakukan oleh Blijâh berbeda dengan algoritma yang diajarkan di sekolah; (2) dalam melakukan operasi penjumlahan dan pengurangan, cara yang berbeda yang digunakan oleh Blijâh yaitu dengan menggenapkan bilangan pertama ke bilangan puluhan diatasnya, berbeda dengan cara yang diajarkan di sekolah, dimana cara yang digunakan yaitu cara bersusun panjang dan bersusun pendek. Hasil penelitian ini diharapkan dapat memberikan inspirasi dan alternatif dalam pembelajaran berhitung di kelas.
\end{abstract}

Kata kunci: algoritma berhitung, Blijâh, operasi bilangan, pendekatan pembelajaran

\section{Blijâh's arithmetic algorithm on Madurese society in Probolinggo Regency: An alternative approach in learning number operation}

\begin{abstract}
The aim of this study was to describe arithmetic algorithm on transaction employed by Blijâh (traditional vegetables seller) in Madurese community at Probolinggo regency, Indonesia. The study was a qualitative approach by means of case study. The data were gathered through observation and interviews. The partisipants of this study were 8 Blijâh living in Paiton, Probolinggo regency, Indonesia. The data were analyzed using Miles \& Huberman model, with analysis step consisting of data reduction, data display, and conclusion. The results of this study obtained some arithmatics algorithm of addition, subtraction, multipication, and division. This paper, however, will only focus on addition and subtraction algorithm. The data reveals that (1) arithmatic algorithm of addition and substraction which used by Blijâh was different from the one taught at school; (2) In performing addition and substraction operations, the different method which used by Blijâh namely replace the first number to tens above it, while the method that taught at school was using long and short-stacke method. The results of this study could be used as one of teaching and learning approach to develop numerical and mental calculation skills.
\end{abstract}

Keywords: arithmetics algorithm, Blijâh, number operation, learning approach

How to Cite: Pratama, L., \& Setyaningrum, W. (2018). Algoritma berhitung Blijâh pada masyarat Madura di Kabupaten Probolinggo: Alternatif pendekatan pembelajaran operasi bilangan. Pythagoras: Jurnal Pendidikan Matematika, 13(2), 203-213. doi:https://doi.org/10.21831/pg.v13i2.15931

https://doi.org/10.21831/pg.v13i2.15931 
Pythagoras, 13 (2), 2018 - 204

Loviga Denny Pratama, Wahyu Setyaningrum

\section{PENDAHULUAN}

Matematika merupakan cabang ilmu pengetahuan yang telah menjadi pusat perhatian dari berbagai elemen kehidupan. Matematika juga merupakan alat dan ilmu pendukung bagi cabang ilmu lainnya untuk mendapatkan solusi dari berbagai permasalahan yang timbul. Selain itu, matematika juga sangat berguna dalam kaitannya dengan kehidupan sehari-hari. Ubayanti, Lumbantobing, dan Manurung (2016, p.16) mengemukakan bahwa matematika tumbuh dan berkembang karena adanya tantangan hidup yang dihadapi manusia di berbagai wilayah dengan latar belakang masyarakat yang berbeda, misalnya pada nelayan masyarakat Papua Barat, Indonesia, mereka mengembangkan matematika dengan cara mereka sendiri selama pembuatan Sero Kokas Fakfak. Selain itu, pendapat lain mengatakan bahwa matematika merupakan bagian dari warisan budaya, sehingga dalam pembelajaran matematika sangat perlu membahas segala sesuatu yang berkaitan budaya lokal (Ulfah, 2016, p.151). Oleh karena itu, matematika dipandang sebagai hasil akal budi atau pikiran manusia dalam aktivitas masyarakat sehari-hari dan budaya lokal. Dari hal tersebut, maka dapat dipahami bahwa penguasaan terhadap matematika mutlak diperlukan dan konsep-konsep dalam matematika harus dipahami secara benar sejak dini.

Reid dan Petocz (2003, p.143) mengungkapkan bahwa matematika merupakan penyusun dari komponen individu yang memusatkan perhatian terhadap aktivitas matematika termasuk dugaan perhitungan. Pendapat tersebut telah tercermin dalam kehidupan masyarakat yang telah melakukan berbagai aktivitas-aktivitas matematika. Misalnya pada aktivitas jual-beli, masyarakat menggunakan konsep matematika yaitu berhitung untuk menghitung uang kembalian, menghitung laba atau rugi, dan lain-lain. Selain berhitung, masyarakat juga melakukan aktivitas matematika seperti membilang atau menyatakan banyaknya sesuatu, serta aktivitas mengukur (mengukur luas sawah, mengukur atau menimbang banyaknya beras, dan lain-lain). Hal ini diperjelas oleh pendapat Hartoyo (2012, p.28) yang menyatakan meskipun masyarakat tidak paham matematika, namun mereka menerapkan konsep matematika yang rumit diterapkan pada aktivitas kesehariannya. Aktivitas-aktivitas tersebut hendaknya dieksplorasi agar masyarakat dapat mengetahui bahwa aktivitas-aktivitas yang mereka lakukan selama ini berkaitan dengan konsep dasar matematika. Selain itu juga agar dapat menjadi referensi bagi para pendidik dalam mengajarkan matematika agar lebih realistik yaitu dengan menghubungkannya dengan kehidupan sehari-hari yang ada di masyarakat tersebut.

Menurut Sirate (2012, p.42), sebagian besar peserta didik mengakui matematika itu penting, namun sebagian dari mereka sering mengalami kesulitan dalam mempelajarinya. Persoalan ini muncul karena adanya ketidaksesuaian yang mereka temukan di luar sekolah yaitu di rumah dan di masyarakat dengan apa yang mereka temukan di sekolah. Barta dan Shockey (2006, p.85) mengakui pula adanya gejala-gejala yang memunculkan wajah seram matematika, sehingga peserta didik menganggap matematika sebagai pelajaran yang membosankan, kurang menarik, dan jauh dari kehidupan sehari-hari. Gejala tersebut biasanya muncul saat siswa mulai mengeluh dengan banyaknya rumusrumus yang diberikan oleh guru saat pembelajaran berlangsung.

Menurut Hilbert dan Cepenter (1992, p.20) pembelajaran matematika di sekolah terlalu bersifat formal dan berbeda dengan yang ditemukan dalam kehidupan sehari-hari, sehingga matematika dipandang sebagai mata pelajaran yang sulit oleh perserta didik. Oleh karena itu sangat penting untuk menggali konsep-konsep matematika yang terdapat dalam kehidupan sehari-hari sehingga konsep tersebut dapat membantu peserta didik dalam mempelajari matematika di sekolah dan juga sebaliknya konsep matematika dapat membatu memecahkan permasalahan yang mereka temui sehari-hari. Namun pada kenyataannya, lingkungan belajar yang ada saat ini cenderung kurang melibatkan koteks yang familiar bagi siswa. Sebagian besar pembelajaran matematika hanya menjadikan dunia nyata sebagai sarana untuk mengaplikasikan konsep yang terkadang dipaksakan, bukan sarana untuk mengembangkan kreatifitas siswa dalam membangun atau membentuk konsep.

Salah satu konsep dasar dalam pembelajaran matematika yaitu algoritma berhitung. Melakukan algoritma berhitung selain membutuhkan kemampuan matematika, juga membutuhkan keterampilan dan ketelitian dalam berhitung. Agar siswa dapat melakukan algoritma berhitung dengan baik, maka siswa harus menguasai konsep, mempunyai keterampilan dalam berhitung serta mengetahui strategi berhitung. Berkaitan dengan ini, Salma dan Amin (2014, pp.174175) mengungkapkan beberapa strategi dalam 
Pythagoras, 13 (2), 2018 - 205

Loviga Denny Pratama, Wahyu Setyaningrum

berhitung, (1) front-end estimation yang fokusnya pada front end atau angka paling kiri. Karena angka ini adalah yang paling penting untuk membentuk penaksiran. Contoh 5,6 $+2,1+6,7+$ 8,1 diestimasi menjadi $5+2+6+8=21$; (2) adjusting, strategi ini dapat digunakan bersamaan dengan semua strategi estimasi dan semua jenis operasi. Misal adjusting with front-end estimation, 5,6+2,4 +6,7 +8,3 diestimasi menjadi $5+$ $2+6+8=21$, angka yang dibelakang koma disesuaikan $0,6+0,4=1$ dan $0,7+0,3=1$. Jadi, $21+2=23$; (3) compatible numbers dimana strategi ini melibatkan pemilihan angka untuk membuat perhitungan agar lebih mudah. Angkaangka yang dipilih akan diubah atau disesuaikan, sehingga dapat dipasangkan dengan angka yang lain. Contoh $24+46+34+63+53+86,24+$ $86 \approx 100,63+34 \approx 100$, dan $46+563 \approx 100$, sehingga hasilnya kurang lebih 300 ; (4) clustering dimana strategi ini melibatkan penambahan banyak bilangan secara bersama-sama ketika bilangan-bilangan tersebut semua di sekitar nilai tertentu. Misalnya $392+420+391$ +414 , ke empat bilangan tersebut nilainya sekitar 400 , sehingga $4 \times 400=1.600$; dan (5) rounding dimana strategi ini melibatkan pembulatan angka dan perhitungan dengan bilangan bulat. Misal 47 $\times 63$ diestimasi menjadi $50 \times 60=3000$. Strategistrategi tersebut jarang kita jumpai di sekolah pada saat siswa mengerjakan soal. Hal ini dikarenakan dalam berhitung pada umumnya siswa diajarkan dengan menggunakan teknik bersusun panjang dan bersusun pendek.

Pada studi ini subjek yang dipilih oleh peneliti adalah pedagang sayur keliling berasal dari suku Madura yang yang tinggal di pulau Madura dan pulau-pulau sekitarnya. Suku ini merupakan suku yang terkenal dengan budaya merantau. Adanya budaya tersebut dikarenakan daerah yang mereka tinggali merupakan salah satu daerah dengan ekonomi rendah di Indonesia. Perantauan mereka ke luar daerah utamanya untuk memperbaiki kondisi ekonomi keluarga mereka. Kebanyakan dari mereka merantau di pulau jawa diantaranya di Kota Surabaya, Kabupaten Probolinggo, Bondowoso, Jember, Situbondo, dan Banyuwangi (Sutoko, 1998, p.42), sehingga mengakibatkan pada Kabupaten Probolinggo banyak ditemukannya masyarakat suku Madura. Pilihan berdagang biasanya diambil oleh perantau Madura di kota-kota besar di Indonesia. Hal ini dikarenakan sejak kecil mereka telah menanamkan pemikiran untuk berdagang (Rifai, 2007, p.37). Melalui berdagang ini berdampak pada kemampuan hitung cepat dikarenakan setiap hari mereka melakukan transaksi jual beli yang tidak lepas kaitannya dengan berhitung. Hal ini juga memicu timbulnya strategi-strategi berhitung yang digunakan saat proses transaksi jual-beli. Oleh karena itu, penelitian difokuskan pada strategi perhitungan yang digunakan oleh penjual sayur tradisional dari Madura di Kabupaten Probolinggo yang dikenal dengan sebutan Blijâh.

Alasan memilih Blijâh sebagai subjek dikarenakan peneliti menemukan adanya keunikan yang dilakukan oleh Blijâh pada saat melakukan transaksi dengan pembelinya. Salah satu transaksi yang dilakukan adalah menghitung total uang belanja para pembeli. Blijâh menghitung dengan cepat tanpa menggunakan kalkulator maupun alat bantu hitung lainnya. Tentunya mereka memiliki cara-cara tersendiri dalam menjumlahkan, mengurangkan, mengalikan atau membagi. Hal ini dibuktikan ketika peneliti pernah mengamati salah satu Blijâh di kecamatan Paiton yang sedang memberi uang kembalian kepada pembeli. Pada saat itu jumlah total belanja yang harus dibayar oleh si pembeli adalah Rp23.000,00 dan pembeli membayar dengan uang senilai Rp50.000,00. Saat memberi uang kembalian, tahap awal yang diberikan oleh Blijâh adalah uang sebesar Rp7.000,00 untuk menggenapi total belanja pembeli sehingga menjadi Rp30.000,00 dan selanjutnya Blijâh menambahkan dengan uang Rp20.000,00 sehingga total uang menjadi Rp50.000,00 kembali. Dengan cara tersebut maka dapat diketahui bahwa kembalian yang diberikan kepada pembeli adalah Rp27.000,00. Dari aktivitas tersebut sudah terlihat bahwa cara pengoperasian bilangan yang dilakukan oleh Blijâh $h$ berbeda dengan cara yang diajarkan di sekolah. Marzuki (2011) mengungkapkan bahwa cara mengoperasikan suatu bilangan yang dipelajari di sekolah, dilakukan dengan cara bersusun panjang dan bersusun pendek yaitu langsung mengoperasikan antara satuan dengan satuan, puluhan dengan puluhan, ratusan dengan ratusan, dan seterusnya yang sesuai dengan tempatnya. Namun demikian, pada kenyataannya masih ditemukan beberapa cara yang digunakan masyarakat dalam berhitung yang berbeda dengan yang dipelajari di sekolah. Oleh karena itu dengan adanya studi ini diharapkan dapat mengungkap aspek-aspek matematika yang terdapat pada algoritma berhitung Blijâh, sehingga dapat digunakan sebagai salah satu alternatif cara atau metode pembelajaran matematika khususnya berhitung. Dengan adanya hal 
tersebut diharapkan siswa dapat mengetahui berbagai macam cara atau strategi berhitung.

Berdasarkan latar belakang masalah berikut kajian teorinya, maka studi ini secara khusus bertujuan untuk mendeskripsikan algoritma berhitung pada transaksi jual-beli yang dilakukan oleh Blijâh (penjual sayur tradisional) dalam masyarakat Madura di Kabupaten Probolinggo, Indonesia. Fokus kajian dalam studi ini yaitu berkaitan dengan operasi hitung penjumlahan dan pengurangan yang dilakukan oleh Blijâh dalam transaksi jual beli.

\section{METODE}

Daerah yang digunakan dalam studi ini bertempat di Kecamatan Paiton, Kabupaten Probolinggo, Jawa Timur, Indonesia. Studi ini menggunakan pendekatan kualitatif dengan jenis studi kasus. Subjek yang digunakan adalah masyarakat yang berasal dari Pulau Madura di Kecamatan Paiton yang berprofesi sebagai Blijâh atau penjual sayur tradisional. Alasan pemilihan daerah studi di Paiton adalah karena kecamatan tersebut merupakan salah satu kecamatan yang mayoritas masyarakatnya berbahasa Madura dalam melakukan aktivitas kesehariannya dan pada daerah ini banyak anak usia sekolah yang beranggapan bahwa matematika itu sulit dan tidak ada kaitannya dengan kehidupan sehari-hari.

Data mengenai algoritma berhitung pada Blijâh dikumpulkan dengan teknik observasi dan wawancara. Sumber data berasalah dari narasumber yang terdiri dari 8 orang Blijâh. Pemilihan subjek dilakukan peneliti dengan cara bertanya kepada masyarakat setempat khususnya ibu-ibu dan beberapa penjual sayur di pasar. Sedangkan instrumen yang digunakan yaitu berupa pedoman observasi dan pedoman wawancara dan dibuat berdasarkan pengamatan awal yang telah dilakukan oleh peneliti mengenai proses transaksi jual beli yang dilakukan oleh Blijâh dan pembeli, terutama dalam proses menghitung hasil penjumlahan, dan pengurangan. Pedoman observasi digunakan sebagai pedoman peneliti dalam melakukan observasi kepada Blijâh saat melakukan transaksi jual beli dengan pembeli. Sedangkan pedoman wawancara digunakan untuk memberikan garis besar pertanyan-pertanyaan yang akan ditanyakan kepada Blijâh saat wawancara. Berdasarkan hal tersebut, maka tenkik wawancara yang digunakan adalah wawancara semi terstruktur.

Data dari observasi dan wawancara kemudian dianalisis dengan cara mengelompokkan data hasil studi yang kemudian direduksi dan disajikan sesuai fokus kajian masalah dan tujuan studi. Analisis data dilakukan dengan menggunakan model Miles dan Huberman (1994) yang terdiri dari tiga alur kegiatan yaitu reduksi data, penyajian data, dan penarikan kesimpulan. Dimana fokus analisis data pada artikel ini mendeskripsikan algoritma berhitung penjumlahan dan pengurangan yang dilakukan Blijâh dalam lingkup masyarakat Madura di Kabupaten Probolinggo, Jawa Timur.

\section{HASIL DAN PEMBAHASAN}

Hasil observasi dan wawancara mencakup aktivitas berhitung yang kemudian dianalisis dan dikaji. Data yang telah diperoleh dan telah dianalisis kemudian direduksi dan disajikan untuk mendapatkan kesimpulan akhir. Data tersebut diperoleh dari 8 subjek penelitian yang kemudian disebut S1, S2, S3, S4, S5, S6, S7, dan S8 yang berprofesi sebagai Blijâh di Kecamatan Paiton, Kabupaten Probolinggo.

Dalam proses jual-beli, Blijâh melakukan aktivitas menghitung yang meliputi penjumlahan, pengurangan, perkalian, dan pembagian. Pada umumnya, sebagian besar Blijâh tidak menggunakan atau menyebut bilangan menggunakan Bahasa Indonesia, melainkan menggunakan Bahasa Madura. Dalam transaksi jual beli, Blijâh maupun pembeli cenderung melakukan penghitungan dengan mengabaikan angka 0 sebagai ribuan. Berikut penjelasan mengenao algoritma berhitung yang dilakukan oleh Blijâh secara detail untuk setiap operasi bilangan penjumlahan dan pengurangan.

\section{Penjumlahan}

Algoritma penjumlahan dapat dilihat ketika Blijâh menghitung total belanja pembeli. Bedasarkan hasil wawancara, ada tiga klasifikasi penjumlahan yaitu, penjumlahan yang keduanya tidak mengandung unsur limaratusan, penjumlahan yang salah satunya mengandung unsur limaratusan, dan penjumlahan yang keduanya mengandung unsur limaratusan.

\section{Penjumlahan yang Keduanya Tidak Memuat} Limaratusan

Jika kedua bilangan yang dijumlahkan adalah pulahan ribuan, misalnya $32.000+$ 19.000. Blijâh menjumlahkan puluh ribuan dengan puluh ribuan maka $30+10=40$. Kemudian menjumlahkan ribuan dengan ribuan $2+9=11$. Kemudian menjumlahkan hasil dari penjumlahan puluh ribuan dengan hasil penjumlahan ribuan yaitu $40.000+11.000=$ 
Pythagoras, 13 (2), 2018 - 207

Loviga Denny Pratama, Wahyu Setyaningrum

51.000. Cara pengoperasian tersebut dapat dilihat pada Gambar 1.

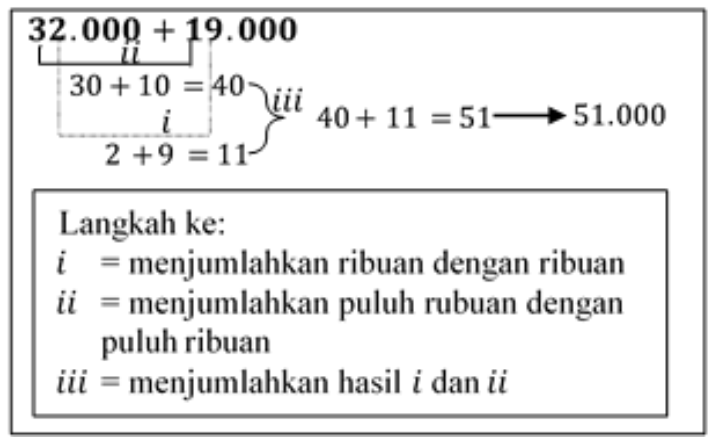

Gambar 1. Cara Pertama Penjumlahan yang Keduanya Tidak Memuat Limaratusan

Cara yang berbeda, jika bilangan yang dijumlahkan adalah puluh ribuan dan ribuan, misalnya $18.000+5.000$. Blijâh menggenapkan 18 ke 20 dengan cara mengambil 2 dari 5 sehingga $5-2=3$. Jadi $18.000+5.000=20.000$ $+3.000=23.000$. Cara pengoperasian tersebut dapat dilihat pada Gambar 2.



Gambar 2. Cara Kedua Penjumlahan yang Keduanya Tidak Memuat Limaratusan

Penjumlahan yang Salah Satunya Memuat Limaratusan

Apabila yang dijumlahkan mempunyai salah satu unsur limaratusan, terdapat 3 cara yang ditemukan. Cara pertama misalnya menghitung $24.500+12.000$. Terlebih dahulu Blijâh menjumlahkan ribuan dengan ribuan yaitu $4+2=6$, lalu menjumlahkan puluh ribuan dengan puluh ribuan yaitu $20+10=30$, lalu menjumlahkan hasil keduanya yaitu $6+30=36$ yang berarti 36.000. Kemudian langkah terakhir mengoperasikan $36.000+500=36.500$ yang berarti Blijâh mengoperasikan 500 di akhir operasi. Cara pengoperasian tersebut dapat dilihat pada Gambar 3.

Pada cara kedua, misalnya menghitung $28.500+16.000$. Blijâh menggenapkan 28.500 ke 30.000 dengan cara mengambil 1.500 dari 16.000 sehingga $16.000-1.500=14.500$. Jadi $28.500+16.000=30.000+14.500=44.500$.
Cara pengoperasian tersebut dapat dilihat pada Gambar 4.

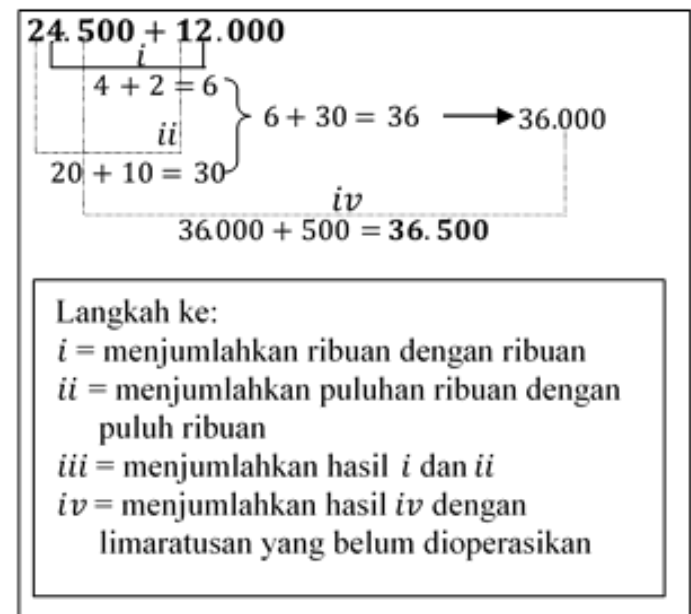

Gambar 3. Cara Pertama Penjumlahan yang Salah Satunya Memuat Limaratusan

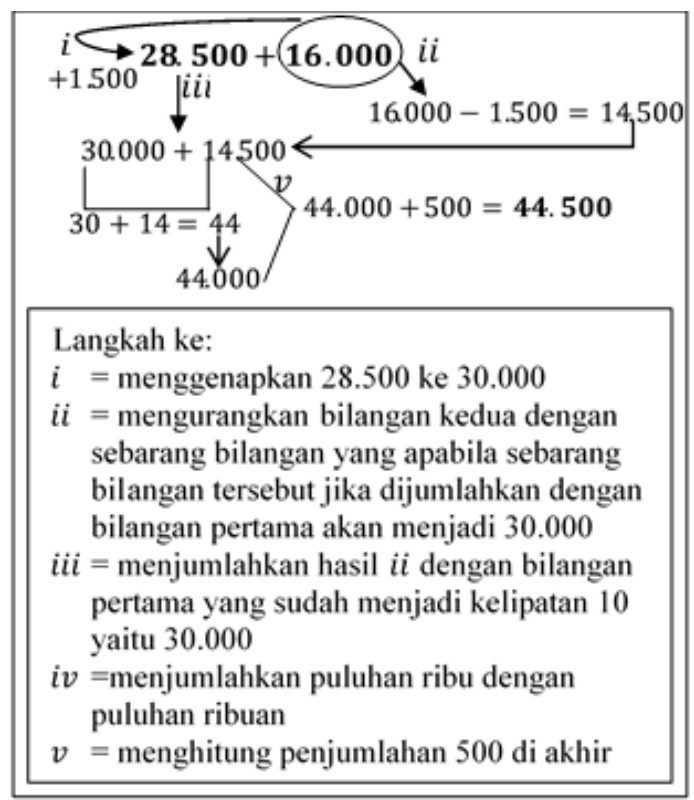

Gambar 4. Cara Kedua Penjumlahan yang Salah Satunya Memuat Limaratusan

Sedangkan pada cara ketiga, misalnya menghitung $23.500+12.000$. Blijâh menjumlahkan puluh ribuan yang kedua dengan bilangan pertama yang dijumlahkan yaitu $23+10=33$. Kemudian menjumlahkan bilangan limaratusan dengan bilangan ribuan yang belum dijumlahkan yaitu $500+2.000=2.500$. Sehingga Blijâh mengoperasikan $33.000+2.500=35.500$. Cara pengoperasian tersebut dapat dilihat pada Gambar 5 . 
Pythagoras, 13 (2), 2018 - 208

Loviga Denny Pratama, Wahyu Setyaningrum

\begin{tabular}{|c|}
\hline 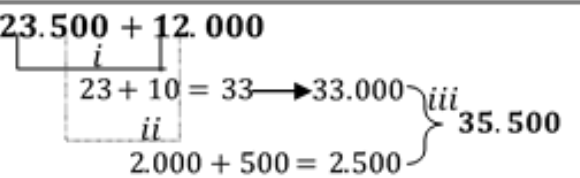 \\
\hline $\begin{array}{l}\text { Langkah ke: } \\
\begin{aligned} i & =\text { menjumlahkan puluh ribuan kedua } \\
& \text { dengan bilangan pertama yang } \\
& \text { dijumlahkan dengan mengabaikan } 0 \\
& \text { sebagai ribuan dan mengabaikan lima } \\
& \text { ratusan } \\
i i & =\text { menjumlahkan bilangan sisa ribuan } \\
& \text { bilangan kedua dengan sisa bilangan } \\
& \text { pertama yang belum dijumlahkan } \\
i i i & =\text { menjumlahkan hasil } i \text { dan hasil } i i\end{aligned}\end{array}$ \\
\hline
\end{tabular}

Gambar 5. Cara Ketiga Penjumlahan yang Salah Satunya Memuat Limaratusan

Penjumlahan Keduanya Mengandung Unsur Limaratusan

Apabila yang dijumlahkan kedua bilangannya mengandung unsur limaratusan, terdapat 3 cara yang ditemukan. Cara pertama, Misalnya Blijâh menghitung $27.500+4.500$. Blijâh mengabaikan 0 sebagai ribuan dan terlebih dahulu mengabaikan limaratusan sehingga $27+4=31$. Kemudian Blijâh mengoperasikan 500 dengan 500 yaitu $500+500=1.000$. Sehingga langkah terakhir $31.000+1.000=32.000$. Cara pengoperasian tersebut dapat dilihat pada Gambar 6

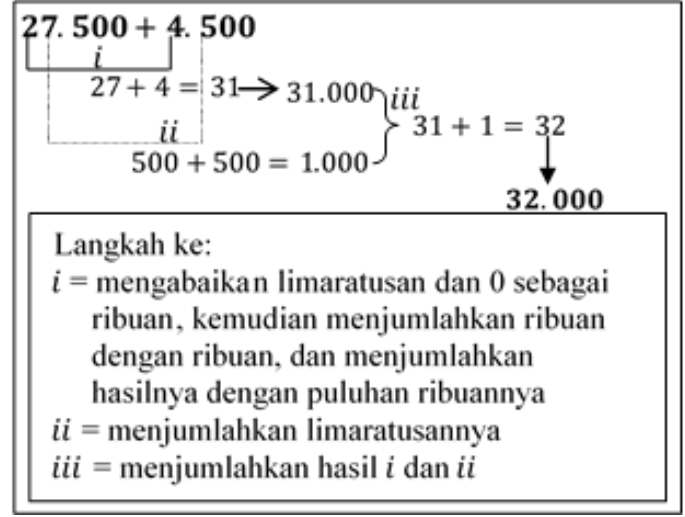

Gambar 6. Cara Pertama Penjumlahan yang Keduanya Memuat Limaratusan

Cara kedua, misalnya menghitung 18.500 + 24.500. Blijâh menggenapkan 18.500 ke kelipatan 10 diatasnya yaitu 20.000 dengan cara mengambil 1.500 dari 24.500 sehingga $24.500-$ $1.500=23.000$. Jadi langkah terakhir $18.500+$ $24.500=20.000+23.000=43.000$. Cara pengoperasian tersebut dapat dilihat pada Gambar 7.

Cara ketiga, misalnya menghitung 23.500 +11.500 . Terlebih dahulu blijah mengabaikan limaratusan dan 0 sebagai ribuan, sehingga Blijâh menjumlahkan puluh ribuan yang kedua dengan bilangan pertama yang dijumlahkan yaitu $10+23=33$. Kemudian menjumlahkan bilangan limaratusan dengan bilangan ribuan yang belum dijumlahkan yaitu $500+1.500=2.000$. Sehingga langkah terakhir $33.000+2.000=35.000$. Cara pengoperasian tersebut dapat dilihat pada Gambar 8 .

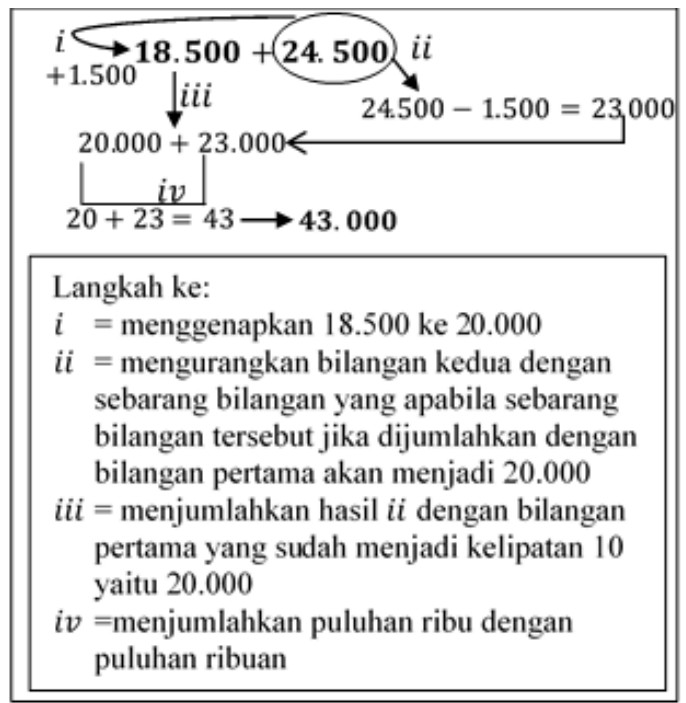

Gambar 7. Cara Kedua Penjumlahan yang Keduanya Memuat Limaratusan

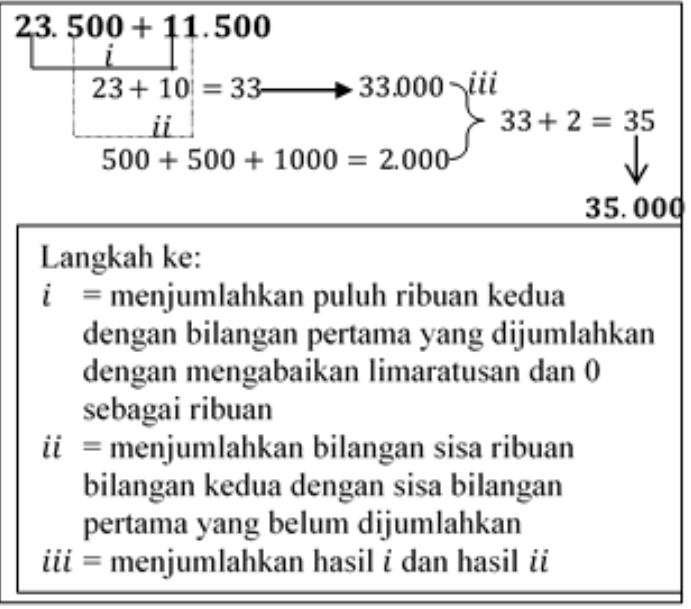

Gambar 8. Cara Ketiga Penjumlahan yang Keduanya Memuat Limaratusan

\section{Pengurangan}

Pengurangan terlihat pada saat pembeli membayar uang kembalian pembeli. Berdasarkan data yang diperoleh di lapangan terhadap kedelapan subjek, cara yang dilakukan untuk menyelesaikan algoritma pengurangan yaitu menggenapkan bilangan pengurangnya ke kelipatan 10 diatasnya dengan cara menambah bilangan tertentu. Misalnya $50.000-13.000=37.000$ maka cara menghitungnya Blijâh menggenapkan 13 ke 
20, menambahkan 7 ke 13 , yaitu $13+7=20$, kemudian Blijâh mengurangi 50 dengan 20, 50 $20=30$. Sehingga total kembalian yang harus dikembalikan Rp37.000,00. Cara pengoperasian tersebut dapat dilihat pada Gambar 9.

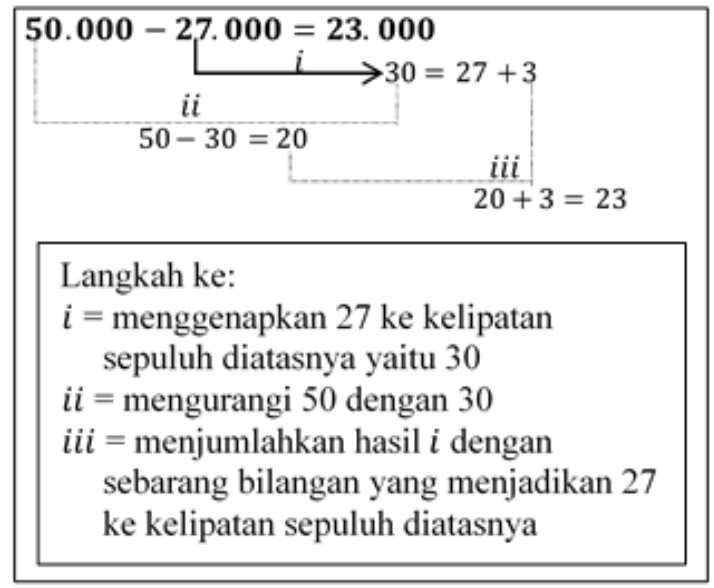

Gambar 9. Cara Pertama Pengoperasioan Pengurangan yang Dilakukan Blijâh

Cara yang berbeda, pada hasil observasi dan wawancara ditemukan strategi yang unik yaitu mengubah bentuk pengurangan menjadi bentuk penjumlahan. Misalnya pembeli membayar Rp50.000,00 dengan total belanja Rp13.000,00 maka Blijâh melakukan cara seperti gambar 10 berikut.

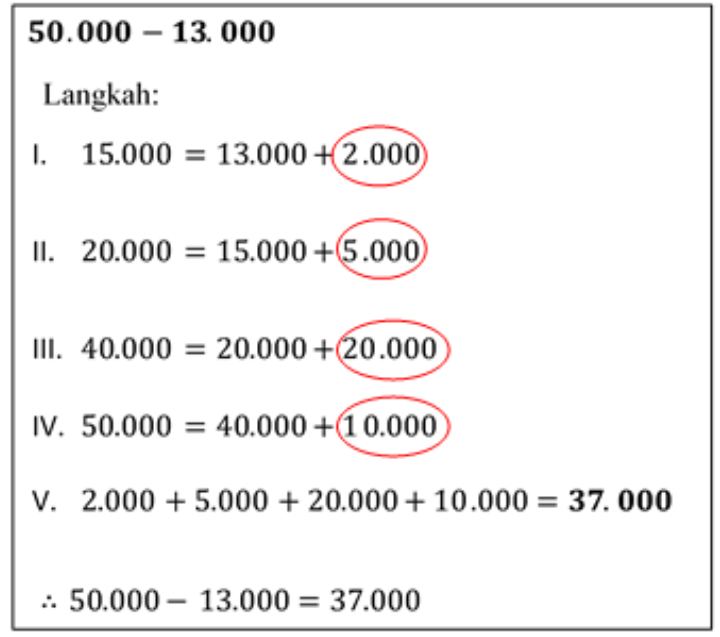

Gambar 10. Cara Kedua Pengoperasian Pengurangan yang Dilakukan Blijâh

\section{Pembahasan}

Pada umumnya, sebagian besar Blijâh maupun pembeli cenderung mengabaikan angka 0 sebagai ribuan, puluh ribuan, maupun ratusan ribu. Mereka cenderung mengucapkan 0, 1, 2, 3, $4, \ldots 9$ untuk ribuan; $10,11, \ldots, 99$ untuk puluhan ribu; serta 100, 101, .., 999 untuk ratusan ribu dengan menggunakan bahasa Madura. Hal ini menarik karena secara tidak langsung mengetahui nilai tempat suatu bilangan karena mereka hanya menyebut puluhan, ratusan atau ribuan saja. Strategi ini dilakukan Blijâh agar mempermudah mereka dalam melakukan perhitungan. Tabel 1 menjelaskan nilai tempat yang digunakan Blijâh.

Tabel 1. Nilai Tempat yang Digunakan Blijâh

\begin{tabular}{ccc}
\hline Nilai & $\begin{array}{c}\text { Pengucapan } \\
\text { Blijâh }\end{array}$ & Nilai Tempat \\
\hline Sebenarnya & 1 & Ribuan \\
1.000 & 10 & Puluh ribuan \\
10.000 & 100 & Ratusan ribu \\
\hline \multicolumn{3}{c}{ Dan seterusnya } \\
\hline
\end{tabular}

Dalam proses jual beli yang dilakukan Blijâh pada masyarakat Madura di Kabupaten Probolinggo sangat erat kaitannya dengan aktivitas matematika. Hal ini sejalan dengan penelitian Hartoyo (2012, p.28) yang menyatakan bahwa meskipun masyarakat tidak paham matematika, namun mereka menerapkan konsep matematika yang rumit diterapkan pada aktivitas kesehariannya. Tanpa disadari Blijâh telah melakukan aktivitas matematika seperti membilang atau menyatakan banyaknya sesuatu terhadap bahan yang hendak mereka jual serta menghitung pada saat transaksi dengan pembelinya. Hal ini sejalan dengan penelitian Ubayanti et al. (2016, p.17) dimana para nelayan masyarakat Papua Barat mengembangkan aktivitas matematika selama pembuatan sero Kokas Fakfak seperti pengukuran yang terkait dengan konsep bilangan dengan menggunakan satuan barang-barang dari bambu dan pembuatan rancangan kapal yang menggunakan konsep Geometri.

Blijâh juga mengembangkan matematika dengan cara mereka sendiri tetapi secara tidak langsung menggunakan konsep matematika yaitu algoritma berhitung untuk menghitung uang kembalian, menghitung laba atau rugi, dan lainlain. Algoritma berhitung tersebut yang jelas tidak dapat terlepas dari operasi penjumlahan dan pengurangan bilangan. Dengan demikian, hal tersebut memberikan suatu pemahaman bahwa algoritma berhitung dapat dibentuk melalui transaksi jual beli yang dilakukan oleh masyarakat. Transaksi jual beli yang dilakukan antara Blijâh dan pembeli bukanlah sesuatu yang dipelajari melalui proses pembelajaran di sekolah, melainkan murni muncul berdasarkan hasil pemikiran dan kebiasaan masyarakat setempat.

Berdasarkan deskripsi mengenai cara $\mathrm{Bli}$ jâh menghitung pada operasi penjumlahan yang 
dijelaskan sebelumnya, dapat diketahui bahwa ada tiga cara yang dapat dilakukan untuk melakukan operasi penjumlahan. Cara pertama yaitu menjumlahkan berdasarkan nilai tempat. Sebagaimana dengan menjumlahkan puluh ribuan dengan puluh ribuan, menjumlahkan ribuan dengan ribuan kemudian menjumlahkan kedua hasil dari masing-masing penjumlahan tersebut. Hal tersebut juga berlaku untuk penjumlahan bilangan yang salah satunya mengandung unsur limaratusan maupun keduanya mengandung unsur limaratusan. Jika bilangan yang dijumlahkan mengandung limaratusan, maka dilakukan penjumlahan berdasarkan nilai tempat dan limaratusannya dihitung pada akhir perhitungan yaitu dijumlahkan dengan hasil akhir dari penjumlahan berdasarkan nilai tempat tersebut. Cara pertama ini sama dengan cara yang diajarkan disekolah yaitu cara bersusun panjang dan bersusun pendek, yang dapat dilihat pada Gambar 11.

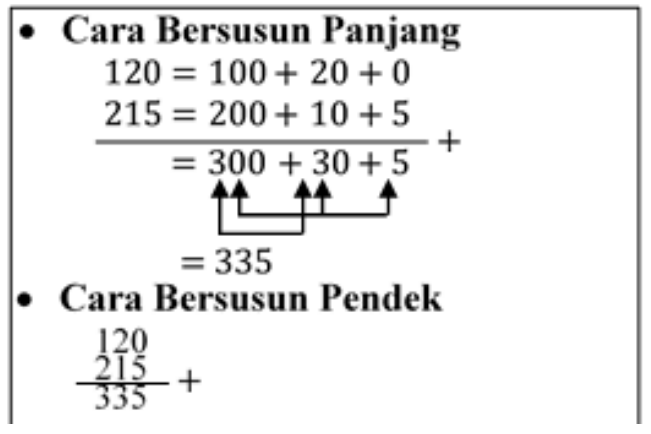

Gambar 11. Cara Bersusun Penjumlahan

Pada cara kedua terdapat perbedaan dengan cara yang diajarkan disekolah. Jika cara di sekolah diajarkan penjumlahan berdasarkan nilai tempat seperti cara pertama, namun beberapa Blijâh menjumlahkan dengan cara menggenapkan bilangan pertama ke bilangan puluhan diatasnya. Kata menggenapkan dalam aktivitas berhitung Blijâh berarti membulatkan bilangan ke kelipatan sepuluh di atasnya. Penjumlahan dengan cara ini biasanya dilakukan jika bilangan pertama yang dijumlahkan adalah bilangan yang dekat dengan pembulatan seperti 16, 27, 38, dan seterusnya yang mendekati ke pembulatan kelipatan sepuluh. Cara yang dilakukan yaitu jika menjumlahkan dua bilangan maka membulatkan bilangan pertama ke bilangan puluhan diatasnya dengan cara bilangan kedua dikurangi dengan bilangan tertentu sedemikian hingga bilangan tertentu tersebut jika dijumlahkan dengan bilangan pertama akan menjadi bilangan kelipatan sepuluh di atasnya. Kemudian kelipatan sepuluh tersebut dijumlahkan dengan bilangan hasil pengurangan bilangan kedua dengan sembarang bilangan tersebut. Cara tersebut juga bisa berlaku untuk penjumlahan salah satunya mengandung unsur limaratusan maupun keduanya mengandung unsur limaratusan tanpa harus melainkan limaratusannya. Pada cara ini sejalan dengan strategi dalam estimasi berhitung yang diteliti oleh Salma dan Amin (2014, p. 174) yaitu menyelesaikan algoritma penjumlahan dengan adjusting. Model operasi penjumlahan cara kedua ini secara matematis dapat dilihat pada Gambar 12.

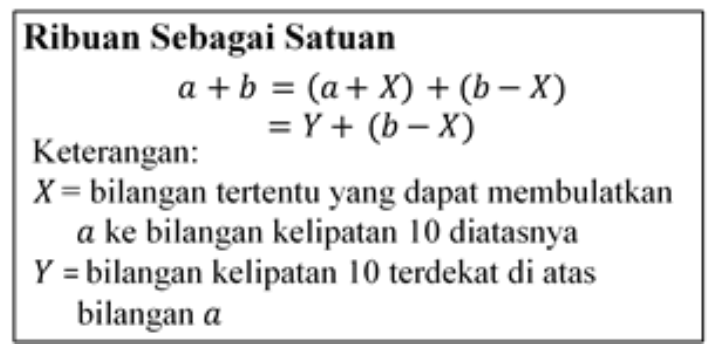

Gambar 12. Model Operasi Penjumlahan Cara Kedua

Menurut Thompson (1999, p.3), strategi yang dipakai pada operasi penjumlahan di atas dikenal dengan nama bridging through ten dimana Blijâh membuat bilangan pengurang itu menjadi bilangan puluhan yang terdekat (menggenapkan ke bilangan puluhan terdekat). Strategi penjumlahan seperti cara kedua ini dapat digunakan sebagai salah satu strategi untuk memperkuat konsep nilai bilangan puluhan dan memperkenalkan konsep keseimbangan dalam operasi bilangan (balancing) yaitu jika satu bilangan ditambah blangan tertentu makan bilangan lain harus dikurangi bilangan tertentu tersebut.

Pada cara ketiga juga terdapat perbedaan dengan cara yang diajarkan disekolah. Cara yang dilakukan yaitu jika menjumlahkan dua bilangan maka menjumlahkan puluh ribuan bilangan kedua dengan bilangan pertama yang dijumlahkan, kemudian hasil dari penjumlahan tersebut dijumlahkan dengan bilangan tertentu yaitu sisa ribuan pada bilangan kedua. Cara tersebut juga bisa berlaku untuk penjumlahan salah satu bilangan yang dijumlahkan mengandung limaratusan maupun kedua bilangan yang dijumlahkan mengandung limaratusan dengan cara menghitung limaratusnya diakhir operasi perhitungan. Model operasi penjumlahan cara ketiga ini secara matematis dapat dilihat pada Gambar 13. 
Pythagoras, 13 (2), 2018 - 211

Loviga Denny Pratama, Wahyu Setyaningrum

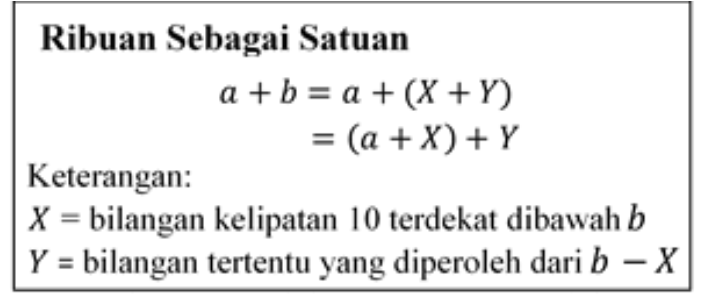

Gambar 13. Model Operasi Penjumlahan Cara Ketiga

Strategi yang dilakukan Blijâh pada Gambar 13 di atas hampir mirip dengan strategi counting on from larger (Thompson, 1999, p.2) dimana seseorang menghitung dimulai dari bilangan yang nilainya paling besar. Jadi Blijâh menjumlahkan ribuan kemudian baru menjumlahkan ratusan dalam hal ini lima lima ratusan. Jadi pada strategi ini meliputi tahap decomposing dimana Blijâh memisahkan ribuan dengan ratusan kemudian menjumlahkan bilangan dari nilai yang terbesar kemudian dilanjutkan ke bilangan dengan nilai lebih kecil.

Pada operasi pengurangan yang dilakukan oleh Blijâh terdapat perbedaan dengan yang diajarkan di sekolah. Cara yang diajarkan di sekolah pada umumnya mengurangkan berdasarkan nilai tempat yang dicapai dengan cara bersusun panjang dan bersusun pendek. Sedangkan cara yang dilakukan Blijâh untuk menyelesaikan algoritma pengurangan terdiri dari dua tahap. Tahap pertama yaitu menggenapkan bilangan pengurangnya ke kelipatan sepuluh diatasnya dengan cara menambah bilangan tertentu. Tahap kedua, bilangan tertentu tersebut dijumlahkan dengan bilangan kelipatan sepuluh tersebut. Atau menghitung mundur dari bilangan kelipatan sepuluh di atas bilangan pengurang yang didapat pada tahap pertama. Model operasi pengurangan ini secara matematis dapat dilihat pada Gambar 14.

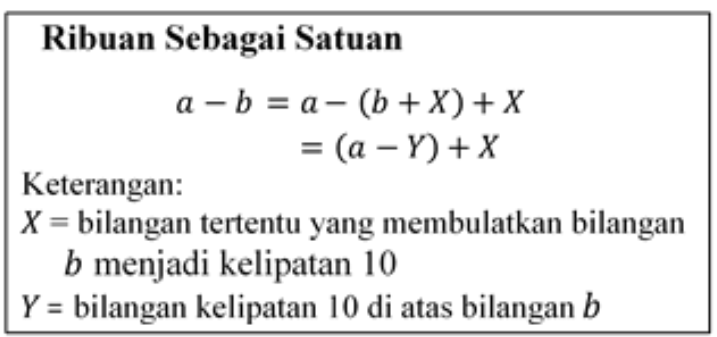

Gambar 14. Model Operasi Pengurangan

Strategi operasi pengurangan yang dipakai Blijâh hampir mirip dengan strategi yang digunakan pada operasi penjumlahan yaitu menggenapkan ke bilangan sepuluhan di atas bilangan pengurang. Menurut Thompson (1999, p.3), strategi ini merupakan perpaduan dari bridging through ten for subtraction (tahap1) dan counting back (tahap 2).

Sekilas algoritma berhitung yang dipakai Blijâh terlihat sederhana tetapi algoritma tersebut melibatkan konsep dan strategi berhitung yang sangat komplek antara lain: konsep keseimbangan dalam berhitung (balancing), konsep nilai tempat, strategi menguraikan nilai (decomposing), dan strategi menghitung dari bilangan yang terbesar, serta mengenapkan ke puluhan di atasnya (bridging through ten). Konsep dan strategi yang digunakan merupakan hal yang penting untuk diketahui dan dipahami siswa di sekolah. Hal ini dapat meningkat kemampuan dan keterampilan berhitung siswa serta dapat mengasah mental komputasi mereka. Komputasi mental merujuk pada proses menyelesaikan operasi aritmatika tanpa menggunkan alat bantu dan biasanya perhitungan dilakukan dengan pikiran (Heirdsfield, 2003, p.60).

Selain itu, penggunaan konteks algoritma Blijâh dalam pembelajaran operasi bilangan di kelas dapat memberikan makna kontekstual yang relevan dan familiar bagi siswa. Hal ini diharapkan dapat membuat pembelajaran matematika lebih bermakna karena berkaitan dengan konteks keseharian yang mereka temui. Menurut Vallori (2014, p.204), pembelajaran bermakna (meaningful learning) dapat meningkatkan pemahaman siswa dibandingkan dengan pembelajaran yang hanya menghafal (rote learning) dalam hal ini menghafal rumus operasi bilangan dan hasil penjumlahan atau pengurangan suatu bilangan. Di sisi lain, konteks algoritma Blijâh juga dapat digunakan sebagai salah satu cara untuk mengintegrasikan budaya dengan pembelajaran di kelas. Integrasi budaya ke dalam pembelajaran di kelas dapat meminimalisir kesulitan siswa belajar matematika (Matang, 2002, p.34).

Menimbang manfaat yang dapat diambil dari algortima berhitung Blijâh, algortima ini dapat digunakan sebagai salah satu alternatif pendekatan pembelajaran di sekolah sehingga siswa tidak hanya belajar konsep operasi bilangan tetapi juga strategi dalam menyelesaikan operasi bilangan serta melatih mental komputasi yang diperlukan untuk numerical skills dan number sense.

Algoritma berhitung Blijâh dapat juga dijadikan sarana untuk memotivasi siswa dalam mempelajari matematika. Algoritma berhitung ini merupakan contoh konkrit dari penerapan konsep matematika dalam kehidupan sehari-hari, sehingga dapat menumbuhkan pemahaman bahwa matematika sangat dekat dengan kehidupan 
sehari-hari. Selain itu, dengan menerapkan algoritma ini dalam operasi berhitung, maka siswa akan menemukan kebermaknaan dari matematika.

Nilai positif yang juga dapat diambil melalui penggunaan algoritma berhitung Blijâh adalah untuk meningkatkan apresiasi terhadap nilai-nilai budaya dan kearifan lokal. Ketika siswa diajarkan mengenai algoritma tersebut, guru dapat memberikan penekanan bahwa algoritma tersebut lahir dari keseharian masyarakat lokal (masyarakat Madura), sehingga akan menumbuhkan keasadaran untuk tetap memelihara nilai-nilai positif yang lahir dari kearifan lokal. Selain itu, belajar dengan menggunakan konteks budaya juga dapat meningkatkan motivasi siswa dalam belajar matematika. Samo (2017) mengemukakan bahwa penggunaan soal-soal pemecahan masalah dengan konteks budaya lokal dapat meningkatkan minat seseorang untuk memecahkan masalah tersebut. Dengan demikian, penggunaan algoritma berhitung Blijâh diduga kuat dapat meningkatkan prestasi belajar siswa, khususnya dalam meningkatkan kemampuan berhitung siswa.

Penggunaan algoritma berhitung Blijâh juga dapat dijadikan sarana bagi siswa untuk melatih kemampuan berpikir tingkat tinggi siswa. Hal ini didasari karena dengan menggunakan algoritma tersebut sangat memungkinkan bagi siswa untuk menemukan berbagai strategi untuk menyelesikan permasalahan terkait operasi hitung, selain strategi formal yang diajarkan di sekolah. Kemampuan siswa dalam menemukan berbagai strategi pemecahan masalah tersebut merupakan bagian diri berpikir kritis dan berpikir kreatif. Beberapa hasil penelitian seperti Apino dan Retnawati (2017); Jailani, Sugiman, dan Apino (2017) melaporkan bahwa kemampuan berpikir kritis dan kreatif yang merupakan bagian dari kemampuan berpikir tingkat tinggi, dapat difasilitasi dengan pembelajaran yang menggunakan berbagai konteks yang bersumber dari kehidupan sehari-hari. Dengan demikian, pemilihan algoritma Blijâh dapat dijadikan sebagai salah satu konteks yang relevan untuk meningkatkan kemampuan berpikir tingkat tinggi siswa.

\section{SIMPULAN}

Berdasarkan hasil analisis dan pembahasan, dapat disimpulkan bahwa terdapat beberapa algoritma berhitung pada operasi penjumlahan dan pengurangan yang dilakukan oleh para Blijâh, dimana algoritma berhitung tersebut berbeda dengan algoritma berhitung yang diajarkan di sekolah. Jika di sekolah siswa diajarkan mengoperasikan bilangan dengan cara bersusun panjang dan bersusun pendek, maka Blijâh memiliki cara lain untuk mengoperasikan bilangan tersebut. Diantaranya pada operasi penjumlahan Blijâh mengoperasikan bilangan dengan cara menggenapkan bilangan pertama ke bilangan puluhan diatasnya. Begitupula dengan operasi pengurangan, Blijâh mengoperasikannya dengan cara menggenapkan bilangan pengurangnya ke kelipatan 10 di atasnya.

Berdasarkan temuan penelitian, ada beberapa saran yang dapat dijadikan masukan bagi siswa, guru, maupun peneliti lainnya. Pertama, hasil penelitian ini dapat dijadikan sebagai salah satu alternatif bagi siswa dalam melakukan operasi berhitung, khususnya operasi penjumlahan dan pengurangan, sehingga siswa mengetahui berbagai macam cara atau strategi yang dapat digunakannya untuk melakukan operasi berhitung. Kedua, meninjau manfaatnya yang dapat memotivasi peserta didik, guru sebaiknya memperkenalkan nilai-nilai matematika dalam kehidupan sehari-hari pada pembelajaran formal sebagai modal awal mengajarkan konsep matematika kepada siswa. Lebih lanjut, algoritma Blijâh memiliki peluang untuk dapat menjadi salah satu alternatif pendekatan pembelajaran operasi bilangan khususnya operasi penjumlahan dan pengurangan bilangan bulat. Selain untuk memberikan alternatif cara dan strategi berhitung, algo-ritma Blijah juga dapat digunakan untuk memberikan konteks yang lebih relevan dan dekat dengan kehidupan siswa sehari-hari. Ketiga, penelitian-penelitian di bidang pendidikan matematika lainnya, khususunya yang berkaitan dengan pemanfaatan budaya dan kebiasaan masyarakat lokal perlu digalakkan, sehingga khasanah pengetahuan matematika akan menjadi semakin kaya, dan bermanfaat bagi masyarakat luas.

\section{DAFTAR PUSTAKA}

Apino, E., \& Retnawati, H. (2017, February). Developing instructional design to improve mathematical higher order thinking skills of students. In Journal of Physics: Conference Series (Vol. 812, No. 1, p. 012100). IOP Publishing.

Barta, J. \& Shockey, T. (2006). The mathematical ways of an aboriginal people: The northern ute. Journal of Mathematics and Culture, 1(1), 79-89

Hartoyo, A. (2012). Etnomatematika pada budaya masyarakat Dayak perbatasan 
Pythagoras, 13 (2), 2018 - 213

Loviga Denny Pratama, Wahyu Setyaningrum

Indonesia-Malaysia. Jurnal Penelitian Pendidikan, 13(1), 29-40.

Heirdsfield, A. M. (2003). "Spotaneous" mental computation strategies. In Pateman, N. A. \& Dougherty, B. and Zilloux, J. (Eds). Proceedings of the international group for psychology of mathematics education conference, pp. 55-62, Honolulu, USA.

Hilbert, J. \& Carpenter, T. P. (1992). Learning with understanding. In Grouws D. A. (Eds). Handbook of research on mathematics Teaching and learning: A project of NCTM. New York, NY: Macmillan.

Jailani, J., Sugiman, S., \& Apino, E. (2017). Implementing the problem-based learning in order to improve the students' HOTS and characters. Jurnal Riset Pendidikan Matematika, 4(2), 247-259. doi:10.21831/jrpm.v4i2.17674

Marzuki. (2011). Meningkatkan prestasi belajar perkalian bersusun menggunakan model kooperatif TAI pada siswa kelas IV SD Negeri 3 Meurah Dua. Lentera Pendidikan. 11(2), 31-39.

Matang, R. (2002). The role of ethnomathematics in mathematics education in Papua New Guinea: Implications for mathematics curriculum. Journal of Educational Studies, 24(1), 27-37.

Miles, M. B., \& Huberman, A. M. (1994). Qualitative data analysis: An expanded sourcebook $\left(2^{\text {nd }} e d\right)$. Thousand Oak, CA: Sage.

Reid, A., \& Petocz, P. (2003). What on Earth is Sustainability in Mathematics? New Zealand Journal of Mathematics, 32, 135144.
Salma, U., \& Amin, S. M. (2014). Profil kemampuan estimasi siswa sekolah dalam menyelesaikan soal cerita. Jurnal Ilmiah Pendidikan Matematika, 3(1), 172-180

Samo, D. D. (2017). Kemampuan pemecahan masalah matematika mahasiswa tahun pertama dalam memecahkan masalah geometri konteks budaya. Jurnal Riset Pendidikan Matematika, 4(2), 141-152. doi: 10.21831/jrpm.v4i2.13470

Sirate, F. S. (2012). Implementasi etnomatematika dalam pembelajaran matematika pada jenjang pendidikan sekolah dasar. Lentera Pendidikan, 15(1), 41-54.

Sutoko. (1998). Geografi dialek bahasa madura. Jakarta: Departemen Pendidikan dan Kebudayaan.

Thompson, I. (1999). Mental calculation strategies for addition and subtraction Mathematics in School. November, 2-4.

Ubayanti, S. C., Lumbantobing, H., \& Manurung, M. H. (2016). Eksplorasi etnomatematika pada Sero (Set Net): Budaya masyarakat Kokas Fakfak Papua Barat. Jurnal Ilmiah Matematika dan Pembelajarannya, 2(1), 12-17.

Ulfah, M. (2016). Keefektifan pembelajaran penemuan terbimbing dengan budaya lokal ditinjau dari prestasi dan motivasi belajar. PYTHAGORAS: Jurnal Pendidikan Matematika, 11(2), 149-159. doi: 10.21831/pg.v11i2.10636

Vallori, A, B. (2014). Meaningful learning in practice. Journal of Education and Human Development, 3(4), 199-209. 